\title{
Simulating a Foreign Policy Dilemma: Considering US Humanitarian Intervention
}

\author{
Bob Switky, Sonoma State University
}

ABSTRACT The humanitarian impulse in the United States routinely clashes with isolationist sentiment, with appeals to the national interest, and with apathy in and out of government. This class exercise encourages students to explore the contours of the debate over humanitarian intervention with a crisis unfolding in Belagua, a fictitious Latin American country. As the crisis deteriorates, students increasingly feel the tension between wanting to help the at-risk civilian population and avoiding a messy conflict from which the United States could have trouble extracting itself. The project requires students to address key questions about the US role in the Belagua case and to consider what the United States could or should have done in actual situations, such as Rwanda and Syria. Because these crises are likely to occur in the decades to come, this exercise initiates students to the challenges that the United States, as well as the international community, undoubtedly will face.

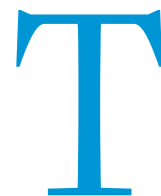

he US approach to humanitarian intervention has fluctuated over time from outright opposition to benign neglect to active participation. The class exercise described in this article encourages students to explore the contours of the debate over humanitarian intervention with a relatively simple, hypothetical situation. The exercise is designed for international relations and American foreign policy courses, but it also is valuable for the foreign policy section of an American government course. The instructor presents students with a crisis in the fabricated Latin American country of Belagua. At first, the situation is tense but, in successive phases of the exercise, students learn that the civilian death toll rises. As the crisis goes from bad to worse, students feel the tension build between wanting to help the increasingly at-risk civilian population and avoiding a potentially messy conflict from which the United States could have trouble extracting itself. After students address key questions about the proper role of US foreign policy in the Belaguan case, they are asked to consider what the United States did-or should have done-in actual situations such as Rwanda, Yugoslavia, Darfur, Libya, and Syria.

This article justifies the value of class simulations as a pedagogical tool, explores the theoretical issues at stake, and describes the simulation content. The article also provides the project's "operating instructions" and modules for adjusting the complexity of the crisis in Belagua. It concludes with methods used to assess student learning.

Bob Switky teaches in the department of political science at Sonoma State University. He can be reached at switky@sonoma.edu.

\section{PEDAGOGICAL CONTEXT: THE VALUE OF SIMULATIONS}

An important advantage of this active-learning exercise is that it allows students to feel the tensions in foreign policy decision making. As Stephen D. Brookfield showed, participating in simulations involves both cognitive and affective domains. Simulations usually induce emotional responses, thereby engaging students "much more directly and vividly than do more reflective activities such as reading or listening" (Brookfield 1990, 115). Regarding Belagua, for example, many students are likely to agonize over the moral implications of their decisions. Unlike a standard lecture in which students are passive listeners, this exercise forces them to confront head on a situation that otherwise could seem abstract and distant. In addition, in this simulation, like others, the complexities of realistic political conflicts can challenge student idealism (Youde 2008).

Most of the class deliberations about Belagua occur in small student groups that represent high-level advisers to the US president. This team-based feature of the simulation compels the participants to confront different views and to examine, or reexamine, their own (Cooper, Robinson, and Ball 2003; McKeachie 2002; Webb and Palincsar 1996). In teams, students become "more aware of their assumptions since they have to respond to each other's request for explanations and justifications to support the various responses proposed" (Brookfield 1990, 116).

Particularly relevant for the Belagua simulation (as described in detail herein), students' active participation also helps to overcome a common problem with appreciating statistics. In a standard lecture, data on casualties can desensitize students to the human cost of civil strife in particular and to war in general. For example, 
lecturing that in roughly three months, 8 oo thousand people were killed in Rwanda will shock some students but leave others almost unaffected or unable to fathom the scope of the tragedy. The problem of gauging the human toll behind the casualty numbers is compounded if the instructor describes the statistics in a sequence of several humanitarian crises. A more active student role in the decisionmaking process of a (hypothetical) tragedy gives more meaning to the numbers and elicits an emotional response that can lead to longer-lasting connections with the relevant concepts.

The Belagua study is divided into two exercises: a simulation followed by an instructor-led analysis of real-life humanitarian crises. This connection between the hypothetical and the actual is a natural extension of the purposes of simulations: (1) to put students in the middle of a challenging problem that forces them to grapple with its many facets; (2) to require students to respond to the problem; and (3) to equip students with the ability to apply their knowledge to similar problems-past, current, and future.

\section{CONCEPTUAL ISSUES AT STAKE}

The simulation is conducive to the exploration of a host of important questions regarding humanitarian intervention. Which questions and how many should be addressed depends on the course, the students' background, and the amount of time allotted to the simulation. Instructors may raise the following questions, or a subset of them, either during the simulation or in the debriefing phase:
- Should the geographic location of the crisis affect US attitudes about intervention?

- In terms of "soft power," does America's reputation help or hurt its ability to intervene?

It is obvious that these questions relate not only to Belagua but to real humanitarian crises as well. The instructor may want to assign background material on actual crises (suggestions are provided later in this article). For the hypothetical case of Belagua, the sample handout described in the next section is designed to provide students with a common background on the fictional country. After the simulation begins, additional information is injected into the crisis, forcing students to adapt as necessary. Instructors may distribute the handout before or at the beginning of the pertinent class session.

\section{SAMPLE HANDOUT ON BELAGUA}

You are a top US foreign policy representative. You and your teammates are tasked with advising the president on what the United States should do, if anything, about the emerging crisis in Belagua.

Belagua is a South American country of 20 million people. It is a fractured country, economically and socially. The urban areas are relatively advanced technologically, but large slums exist on the outskirts of the cities. Most people in rural areas live on subsistence agriculture, and the country has only modest reserves of oil. The Belaguan people are composed of several ethnic groups.

\section{The simulation is conducive to the exploration of a host of important questions regarding humanitarian intervention. Which questions and how many should be addressed depends on the course, the students' background, and the amount of time allotted to the simulation.}

- Should states refrain from humanitarian intervention?

- Should humanitarian intervention be justified only when international peace and security are threatened? Or, to what extent should morality drive US foreign policy? (Kissinger 2001; Lechner 2010)

- Do states have an individual or collective responsibility to protect civilians threatened by their own government? (Bellamy 2011; Cassese 2001)

- Are people around the world so increasingly interconnected that a crisis in one country must elicit an attempted resolution by the international community, including the United States?

- If humanitarian intervention becomes a permanent component of US foreign policy, which rules should govern the decision to intervene? Under which circumstances is US-led intervention likely to do more harm than good?

- What constitutes a "crisis" worthy of international and US intervention? (Evans and Sahnoun 2002)

- If the United States and the international community endorse humanitarian intervention in principle, what are the implications for the state-centric international system and international law? Hugo Grotius may be invoked here: "[W] here tyrants provoke their people to despair and resistance by unheard of cruelties, having themselves abandoned all the laws of nature, they lose the right of independent sovereigns, and can no longer claim the privilege of the law of nations" (Scott 2004).
The minority, lighter-skinned ethnic group resides mostly in the urban areas and, despite being a minority, has historically held the reins of political and economic power. Many in this group also have long held the belief that the country's darker-skinned people are "backwards" and best suited to farming or low-skilled factory work. Attitudes toward those in power exhibit similar stereotyping.

The government maintains a near monopoly on the news media and occasionally censors Internet activities. Complicating matters for all of Belagua is the growing presence of violent criminal organizations whose activities center on illegal drugs. Their operationswhich include primarily the transportation but also the cultivation of illegal drugs-have had a destabilizing effect not only in Belagua but also in neighboring countries.

In the past several years, many from the poorer segments of Belaguan society have formed antigovernment citizens' groups and militias. Among other demands, they want greater government representation and more political rights, including freedom of the press. The Belaguan government believes it has responded constructively to the growing social unrest. Three years ago, it passed a law granting a $30 \%$ quota for government jobs to people from rural communities. Two years ago, the government passed several laws making it easier for workers to form or join unions. It also abolished a law that made it a crime to criticize the government.

However, many government opponents are dissatisfied with these changes, arguing that the reforms have, at best, yielded only 
minor improvement to the political influence of the majority of the country's citizens. At worst, critics contend, the reforms exist only on paper. Acting partly out of frustration, antigovernment militias have attacked government buildings, including several police stations. Four months ago, a bomb attack at a shopping mall resulted in the deaths of 150 people, among them women and children. Reports from Belaguan newspapers, CNN, and foreign Spanish-language news services all predicted more militia attacks in the near future. The accuracy of many of the blogs, tweets, and posts on Facebook is difficult to assess, but the information from these outlets tends to confirm the conclusions of the mainstream news media.

In response to the attacks, the Belaguan government retaliated with brutal force. According to Amnesty International (AI) and Human Rights Watch (HRW), the government is responsible for as many as 1,200 of the 1,800 people killed so far. Those killed by government forces (or "death squads," as government critics call them) were mostly civilians-not militia members. However, the government claims that the people killed were either members of the rebel groups or those who provided support to the group's operations (e.g., giving food, lodging, and directions through the dense jungle). AI and HRW believe that some but not all of the militia leaders are coercing civilians to help them. Alleged tactics used by the militia to achieve compliance include extortion, threats, and physical and sexual violence.

Calls from the Organization of American States (OAS) and many United Nations (UN) members are growing louder for something to be done to stop the violence on all sides. Doctors Without Borders, the first non-governmental organization (NGO) on the scene, argued that if the international community does not act soon, the situation could get much worse. Its reports, in conjunction with much of the social media, indicate that thousands of people are at risk of violence from both government and antigovernment forces.

As you contemplate your recommendation to the president on how the United States should respond to the situation in Belagua, please address the following questions: student simulation portion followed by a lecture portion. The short version can take one hour whereas the longer version can take two hours or more. As described in this section, the difference is determined by how many details the instructor wants to include in the simulation and how many actual humanitarian crises are incorporated into the lecture portion of the class.

Similar to many active-learning techniques, the instructor's role during the simulation is somewhat limited; preparation is essential to its smooth running. First, details about Belagua presented to the students (see the sample handout in the previous section) may need to be adjusted to suit the instructor's preference for the level of detail. Second, the instructor must establish student groups, define student roles, clarify activities for each phase of the simulation, and determine the appropriate debriefing method.

\section{Preparation: Adjusting the Content}

The content of the Belaguan situation can be modified to meet the needs of the particular course and the capabilities of the students. For example, if the class consists of self-selected students who are quick to support humanitarian causes, the number of people at risk in Belagua can be reduced. The instructor also may want to change other details about the Belaguan scenario. The role of the Belaguan government or the militias can be modified so that one is guiltier of human rights abuses. The instructor may inform students that some human rights NGOs, several (but not all) prominent members of Congress, and many journalists advocate diplomatic action, whereas others oppose arming the opposition out of fear of even greater violence. An additional infusion of information could be that illegal arms (in varying quantities) are finding their way to the rebels from neighboring countries. Students would then have to determine whether the United States, some other body (e.g., neighboring countries, the OAS, or the UN) or some combination should attempt to stem or encourage this flow of arms.

\section{Using a (hypothetical) Latin American country affords the opportunity to include the dynamic of historical animosity that many Latin American countries have toward US intervention and perceptions of American imperialism. It also provides the opportunity for students to consider immigration implications from the crisis.}

(1) What US interests, if any, are directly or indirectly affected by what is happening in Belagua?

(2) Should the United States do anything for Belagua and, if so, what? If the United States becomes involved, should it act alone, with other countries, or with international organizations (i.e., intergovernmental organizations [IGOs] like the UN and the North American Treaty Organization and international NGOs like AI and HRW)? Should the United States provide both diplomatic and military help? If so, what might that "help" look like: US military personnel on the ground in Belagua, a no-fly zone, or something else? Be as specific as possible.

\section{OPERATING INSTRUCTIONS}

The length of the exercise is determined by the instructor's goals and corresponding time constraints. The exercise consists of a
The location of the hypothetical country also may be changed. For this simulation, however, Latin America was chosen because it is likely to have more geographic relevance to students on American college campuses. Using a (hypothetical) Latin American country affords the opportunity to include the dynamic of historical animosity that many Latin American countries have toward US intervention and perceptions of American imperialism. It also provides the opportunity for students to consider immigration implications from the crisis.

Some details may be eliminated to simplify the exercise. The racial divide in Belagua, for example, could be deleted. The rationale for including it was to appeal to students who might argue that US involvement should be avoided because the social dynamics of the country are too complex. The larger argument would be that US intervention is likely to exacerbate existing social tensions; therefore, US involvement should be avoided. 


\section{Preparation: Setting Up Groups and Student Roles}

This project centers on teams and therefore can be used in classes of almost any size. The ideal group consists of four students. Groups with fewer students may be necessary in smaller classes; however, groups of fewer than four reduce the opportunity for the crossfertilization of ideas. Groups of five students are acceptable, but more than five can be unwieldy. Instructors may choose to assign students to specific groups or use random selection. If possible (depending on how well the instructor knows the students), each team should have a mix of students based on gender, class ranking, ideological orientation, and so on. Alternatively, students may form their own groups; however, the weakness in this approach is that like-minded students may succumb to "groupthink" and be less willing to contemplate alternatives. This weakness, however, can be reduced at least partially during the full-class discussions, in which a homogeneously thinking team must confront different views from other groups.

Each team should have a discussion leader (i.e., facilitator) to ensure that each member can provide input and that extreme extroverts do not monopolize the group's discussions. Depending on student dynamics, the instructor may assign the leader or allow the groups to choose their own. Each team should also designate a student to record the team's ideas (i.e., the scribe). Another student should be chosen to speak for the team when presenting the group's findings to the class.

If the instructor wants to add more realism to the exercise, any of the following roles may be assigned: secretary of state, undersecretary of state for Latin American affairs, national security advisor, director of national intelligence, director of the Central Intelligence Agency, and so on. For a significant expansion of the exercise, roles that focus on non-American actors may be included as well. Examples include representatives of the Belaguan government; one or more dissident groups; and representatives of the Roman Catholic clergy, OAS, European Union, UN, and international peace groups.

Preferably, these tasks should be performed before the class session in which the simulation will take place. The handout (in paper or electronic form) can be made available before the class meets so that students can work more quickly on the day of the simulation exercise. presented to the class. Students should be prepared to answer the two questions listed at the end of the handout.

After students have deliberated, the instructor calls on three or four groups to present their policy choices to the class. The instructor may ask if other groups chose options significantly different from those already presented. Alternatively, teams that did not formally present their findings may critique the decisions already presented. Depending on the level of contentiousness among students, this phase may last from five to 15 minutes. Discussion should be limited, however, to save time for the remainder of the exercise.

\section{Phase 2: Update to Conditions in Belagua}

This phase of the simulation repeats the process in Phase 1 (i.e., address the two key questions and present and debate US options) but with an important change to the situation in Belagua. The instructor informs the class that recent news reports indicate that the crisis in Belagua has worsened. Initially, 1,80o people were reported dead. In the ensuing weeks, the death toll has risen to 6,ooo. Several anonymous but thus far highly regarded reports from the blogosphere indicate that the number of casualties is probably even higher. Two YouTube posts that show bloody clashes between government forces and civilians have gone viral.

The teams are now given time to reassess their previous advice to the president. The students prepare explanations for why they chose to remain with or change their initial recommendation. After they have been given about five to 10 minutes to render a decision, another class discussion ensues.

\section{Phase 3: Further Updates to the Situation in Belagua}

In this next phase of the exercise, more than 30,00o people have reportedly been killed in Belagua. If desired, the instructor can put the death toll at 90,000, or even 200,000, at this or in an additional phase of the simulation. Another feature of this phase is that three American journalists (or American exchange students or Americans working for an NGO) have been killed in government raids on a suspected rebel stronghold. As before, students are given time to decide whether to stay with their prior advice, the instructor solicits the teams' views, and discussion ensues. This marks the end of the role-playing part of the simulation exercise.

\section{After running this exercise many times, it is clear that abstract concepts related to humanitarian intervention "come to life" when students confront the many dilemmas inherent in the Belaguan crisis.}

\section{Phase 1: Initial Student Reactions to Belagua}

Students should be given about 10 minutes to absorb the handout's material and decide how to respond to it. The instructor should remind students that their job is to present the president with policy options for dealing with the crisis and to clarify the merits and shortcomings of those options. This time frame is restricted to save time for later group discussions. (If more time is available, 15 to 20 minutes allows a richer airing of the issues at stake during this early stage of the simulation.) Any issue not hashed out in the first 10 minutes can be reconsidered in subsequent phases of the exercise. If a group reaches a consensus on the policy choice, it should justify why its preferred option is better than the others. The instructor informs students that their team's conclusions will eventually be

\section{Phase 4: Belagua Meets Reality}

Although the simulation portion of the exercise is formally over, a vital part of the students' learning experience involves linking Belagua to the real world. The instructor should provide a description of two or more actual humanitarian crises. The main purpose is to encourage students to make a connection between their choices regarding Belagua and what the United States did in the humanitarian crises described by the instructor. In addition to the studies mentioned previously, the works by Barnett (2011), Fisher (2011), Kristof (2012), and Stewart (2012) are recommended. The Council on Foreign Relations maintains a website devoted to humanitarian intervention at http://www.cfr.org/issue/humanitarian-intervention/ ri110. 
Depending on the course (e.g., a lower-division American government course or an upper-division foreign policy course), the depth of detail provided in the overview of humanitarian crises can vary. At a minimum, the descriptions should provide information about the country's relevant domestic as well as international actors (i.e., states, IGOs, and NGOs) that played, or could have played, a role. Of course, the instructor should also present a brief overview of US actions during the given crises. It also may be helpful to distribute a handout listing major twentieth-century atrocities. I have found that students with little or no knowledge of past humanitarian crises are shocked at the scope of the tragedies. Some-but not all-previously noninterventionist students have reported rethinking their "stingy" attitudes. In terms of time management, the duration of the instructor's description of two or more crises is malleable.

\section{Phase 5: Debriefing}

This final phase of the exercise is designed to cement the day's most important lessons. The debriefing may be instructor-led or student-led. The instructor, for example, could review the day's most important themes and make specific links to US behavior during real-life humanitarian crises and class dynamics in the Belaguan simulation. The instructor could reiterate and clarify the arguments for and against the "responsibility to protect." Depending on the desired level of complexity, the instructor may want to discuss the role of domestic political groups in influencing US foreign policy. The instructor also should explore the controversial dynamics between wanting to do right by one's fellow human beings and doing right by one's country. Finally, instructors may ask students what pleased or concerned them about the class's handling of the Belaguan crisis (Brookfield 1990, 127).

If the student-led approach is adopted, instructors should have each group compile a written description of at least three important lessons from the exercise. If there is sufficient time, each group can present one or more of its lessons to the class. It is helpful if the groups submit their papers so that the instructor can record which lessons were or were not absorbed. The complete list of student lessons then can be posted online or distributed in the next class session.

A final question will enhance the debriefing process and help with running the Belaguan case in subsequent classes. Instructors should ask students what was realistic and unrealistic about (1) how students acted in the simulation exercise, and (2) the simulation itself.

\section{ASSESSMENT METHODS}

Several techniques may be used to assess students' learning about humanitarian intervention. There could be an essay question on an exam that requires students to grapple with one or more of the major questions raised in this article. The essay topic should be designed so that students are required to provide examples from an actual humanitarian crisis and the experiences of the Belaguan simulation. Alternatively, instructors may assign a one- to threepage paper that explains how the students' personal views were affected by the Belaguan case, by their teammates, and by the humanitarian crises described by the instructor or from a reading assignment.

After running this exercise many times, it is clear that abstract concepts related to humanitarian intervention "come to life" when students confront the many dilemmas inherent in the Belaguan crisis. As a result of the project, the class has been livelier as teams debate, sometimes heatedly, whether the United States should intervene-given a death toll of 1,800 or 200,000 . Test results also indicate a greater depth of understanding as a result of the simulation exercise. Because humanitarian crises are likely to be a feature of international affairs in the decades to come, this exercise initiates students to some of the challenges the United States, as well as the international community, undoubtedly will face.

\section{ACKNOWLEDGMENTS}

For helpful comments on earlier drafts of this article, I thank Carolyn Shaw of Wichita State University; Kathy Charmaz, Sheila Katz, and Don Romesburg of Sonoma State University; and anonymous reviewers.

\section{R E F E R E N C E S}

Barnett, Michael. 2011. Empire of Humanity: A History of Humanitarianism. Ithaca, NY: Cornell University Press.

Bellamy, Alex J. 2011. Global Politics and the Responsibility to Protect. New York: Routledge. (See chap. 3, "Humanitarian Crises since 2005.")

Brookfield, Stephen D. 199o. The Skillful Teacher. San Francisco: Jossey-Bass, Inc. Cassese, Antonio. 2001. International Law, 349-74. Oxford: Oxford University Press.

Cooper, J., P. Robinson, and D. Ball. 2003. Small Group Learning in Higher Education: Lessons from the Past, Visions of the Future. Oklahoma City, OK: New Forums Press.

Evans, Gareth, and Mohamed Sahnoun. 2002. "The Responsibility to Protect." Foreign Affairs 81 (6): 99-110.

Fisher, David. 2011. Morality and War: Can War Be Just in the Twenty-First Century? New York: Oxford University Press.

Kissinger, Henry A. 2001. "The Pitfalls of Universal Jurisdiction.” Foreign Affairs $80(4): 86-96$.

Kristof, Nicholas D. 2012. "Obama AWOL in Syria.” New York Times, August 8. A23.

Lechner, Sylvia. 2010. "Humanitarian Intervention: Moralism versus Realism?” International Studies Review 12 (3): 437-43.

McKeachie, W. 2002. Teaching Tips: Strategies, Research, and Theory for College and University Teachers, 12th ed. Boston: Houghton Mifflin Company.

Scott, Shirley V. 2004. International Law in World Politics. Boulder, CO: Lynne Rienner.

Stewart, Rory, and G. Knaus. 2012. Can Intervention Work? New York: W. W. Norton.

Webb, Noreen M., and A. S. Palincsar. 1996. "Group Processes in the Classroom.” In Handbook of Educational Psychology, ed. David C. Berliner and R. C. Calfee, 841-73. New York: Simon \& Schuster Macmillan.

Youde, Jeremy. 2008. "Crushing Their Dreams: Simulations and Student Idealism." International Studies Perspectives 9 (4): 348-56. 